\section{Effect of Cleanser Solutions on the Retention Force of 0'ring Attachment: An in Vitro Study}

Daniela Nair Borges Felipucci ${ }^{1} \mathbb{D}$, Patricia Almeida Curylofo ${ }^{1} \mathbb{D}$, Luciana Costa Crizóstomo ${ }^{1} \mathbb{D}$, Luis Geraldo Vaz $\mathbb{1 D}^{\mathbb{D}}$, Suleima do Vale Alves ${ }^{1} \mathbb{B}$, Ana Paula Macedo ${ }^{1}$, Valéria Oliveira Pagnano ${ }^{1}$ (D)
'Ribeirão Preto School of Dentistry, USP - Universidade de São Paulo, Ribeirão Preto, SP, Brazil

${ }^{2}$ Araraquara School of Dentistry, UNESP - Universidade Estadual Paulista, Araraquara, SP, Brazil

Correspondence: Valéria Oliveira Pagnano, Avenida do Café $\mathrm{S} / \mathrm{N}$, 14040-904 Ribeirão Preto, SP, Brasil. Tel: +55-16 3315-4795. e-mail:valpag@forp.usp.br

Key Words: denture cleanser, overdenture, scanning electronic microscopy, retention.

\begin{abstract}
The aim of this study was to evaluate the effect of cleaning solutions on the retention force of o-ring-type overdenture attachments. The effect of four solutions on nitrile rings were evaluated: Cepacol (C), Cepacol with fluoride (CF), Listerine (L) and 0.05\% sodium hypochlorite (SH); deionized water (DW) was used as a control. Matrices containing two implants and abutments and acrylic specimens with the metal capsules were obtained and divided into the groups. A simulation of 90 overnight immersions ( $8 \mathrm{~h}$ ) was performed, and the tensile strength value was obtained the beginning (T0) and in every 30 days $(\mathrm{T} 1, \mathrm{~T} 2$ and T3) $(\mathrm{n}=6)$. In order to analyze o-ring surface damage after the immersions, a scanning electron microscopy (SEM) was used $(n=1)$. For statistical analysis of the results, analysis of variance (ANOVA) and multiple comparisons with Bonferroni adjustment (test power $=1.000 ; \alpha=0.05)$ were used. There was a significant difference for the factors time $(p<0.001)$, solution $(p<0.001)$ and for the interaction time $\times$ solution $(p<0.001)$. Considering the times of each solution, only for DW there was no significant loss of retention over time. Comparing the solutions in each moment, there was no difference among the solutions in T0. From T1, CF and SH provided less retention than DW $(p<0.005)$. Through SEM it was possible to observe changes in the surface of the $\mathrm{CF}$ and $\mathrm{SH}$ nitrile o-rings. $\mathrm{CF}$ and $\mathrm{SH}$ should be avoided due to deleterious action in o-rings.
\end{abstract}

\section{Introduction}

Edentulous patients can be rehabilitated satisfactorily through implant-retained overdentures, eliminating problems common to conventional denture users, such as pain, decreased bite force (1), unsatisfactory retention, stability, aesthetic and phonetic (2), that too much compromise masticatory function (1). Thus, this type of prosthesis provides fewer injuries to the supporting tissues and more comfort to patients and increases their satisfaction with the rehabilitation treatment $(3,4)$.

In the case of the edentulous jaw, the treatment of choice has been two-implant-retained overdentures $(5,6)$. Some types of attachment have been proposed to make the connection between the dentures and dental implants. Among them, the most common attachments utilized are the ball and socket and the bar and clip systems. For cases of two implants, those most used have been Locator-type connection systems and ball or o-ring systems $(7,8)$.

Studies have shown that o-ring systems, which consist of a metal casting with a rubber ring embedded in the base of the prosthesis, involving a spherical abutment attached to the implant (9), provide easy of insertion and removal, less Candida albicans colonization (10), low cost and easy post-installation maintenance by replacing only the retaining ring. However, there are disadvantages such as the gradual loss of retaining rings and the need for periodic replacement $(7,9,11,12)$. Some of the reasons for this retention loss are a lack of parallelism between implants $(13,14)$, and component fatigue (14).

Daily cleaning of the prosthesis is extremely important for the longevity of treatment. Thus, cleaning procedures are recommended to overdenture wearers (15). The most common method of denture cleansing is brushing with water and toothpaste or soap (16). Since brushing alone is not sufficient for biofilm control $(17,18)$, the combination of chemical and mechanical methods, such as chemical methods that allow access to the undercuts that accumulate biofilm, have provided satisfactory results in an attempt to promote cleansing of the prosthesis in its entirety (19).

Chemical solutions include disinfectants based on alcohol, sodium hypochlorite, alkaline peroxides, enzymes and organic or inorganic diluted acids (16). Citric acid and alkaline peroxide (sodium perborate/enzymes) are among those most recommended (20), due to their effectiveness in the removal of biofilm (21). Sodium hypochlorite has satisfactory antimicrobial and antifungal properties, removes stains and dissolves some substances (22), however, several authors have reported deleterious effects on dental 
prosthesis, such as whitening of the acrylic resin bases, metal oxidation and liner degradation if they are used incorrectly $(16,21,23)$.

The overdenture removal and replacement can cause surface fatigue with a consequent decreasing in retention and denture wearing. The action of cleansers can cause corrosive effects on these dentures (24), but few studies have demonstrated the action of cleansers in overdenture attachments $(15,18,23-26)$. Reviewing the literature, the action of sodium hypochlorite is quite controversial, some authors have reported reduced retention force $(15,18,24,26)$ while Varghese et al. (25) demonstrated that $5.25 \%$ sodium hypochlorite increases the retention of yellow Hader clips. For effervescent tablets, no significant changes were found in the study of Varghese et al. (25), however, a retention decrease is described in other studies $(23,25)$. For the essential oils (Listerine), it was only reported an increase in retention $(15,18)$.

Since several studies have diverse results, there is no consensus in relation to the most indicated overdenture cleanser. Further research is necessary to evaluate the properties of cleansers to provide clear guidance to dentists $\vec{s}$ on which products are safer, considering the possible adverse effects, for establishing a hygiene protocol for overdentures users. Thus, the purpose of this study was to evaluate the effects of four different cleansing solutions on the retention values of o-ring attachments. The null hypothesis tested was that after three months of simulated use, there is no difference in the retention of o-rings soaked in: $0.05 \%$ sodium hypochlorite (SH), Cepacol (C), Cepacol with fluoride (CF) and Listerine (L).

\section{Material and Methods}

The methods to obtain the specimens were based on those previously described by Botega et al. (11) and Nguyen et al. (15). Two internal hexagonal implants analogs with a diameter of $3.75 \mathrm{~mm}$ and length of $10 \mathrm{~mm}$ (Conexão Sistemas de Próteses Ltda, Ribeirão Preto, SP, Brazil), were parallel positioned with a distance of $22 \mathrm{~mm}$ between each implant in a Teflon holder $(2.0 \mathrm{~cm}$ high $\times 3.5 \mathrm{~cm}$ in diameter). Subsequently, there was the placement of the

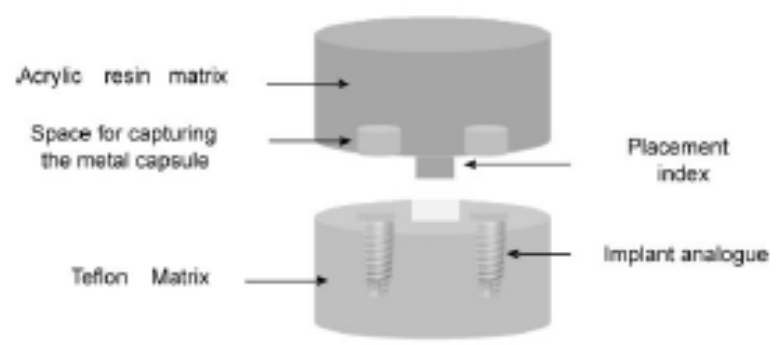

Figure 1. Matrix for capturing metal capsules. abutments into the analogs, and the capture of the metal capsules in this support.

It was developed another Teflon matrix to reproduce the base of the prosthesis, with enough relief for future accommodation of the metal capsules. Spacers were used for this purpose.

The upper matrix was positioned on the analogs for capturing the metal capsules and nitrile rubber rings (Fig. 1). It was then filled with chemically activated acrylic resin (Vipi Flash, Vipi Dental, Pirassununga, SP, Brazil), handled according to the manufacturer's instructions. After complete polymerization of the acrylic resin, the block was removed and polished.

The 30 specimens were randomized distributed among the solutions groups (Table 1) $(n=6)$ and deionized water (DW) was used as a control. The specimens were immersed in different plastic containers (Ziploc, S.C. Johnson \& Son, Inc., Sao Paulo, SP, Brazil) containing $50 \mathrm{~mL}$ of each solution. The containers were kept hermetically sealed and stored in an oven with constant temperature set at $37^{\circ} \mathrm{C}$.

The simulation of 90 days of immersion (three months) was applied for all groups and the solutions were changed each $8 \mathrm{~h}$, representing the clinical procedure of overnight immersion. Experimentally, 10 days had represented a period of 1 month (total time $=30$ days) (18). After 10 days, the tensile strength tests were performed every 10 days, and during this interval, the specimens were stored in artificial saliva (Fig. 2).

\section{Retention Measures}

Six specimens from each group were used for the tensile strength tests performed using a mechanical testing machine (MTS 810, Eden Prairie, Minneapolis, MN, USA). This machine was programmed to insert and remove the components, respecting the long axis of the implant. There was a metal support allowing the fixation of the test model

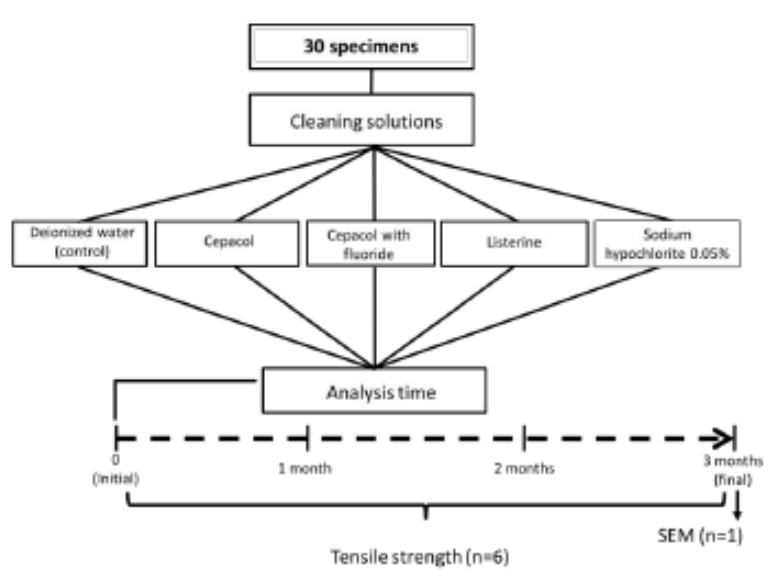

Figure 2. Flowchart illustrating the sequence of readings. 
and the devices onto the test machine cheek (11).

Retention force values were calculated before the immersion period (T0) and after simulation of 30 (T1), 60 (T2) and 90 (T3). The tensile strength test was performed using a 2.5-kN load cell and a constant velocity of $1 \mathrm{~mm}$ min $^{-1}$ (Test Works for Test Star - MTS 810, Eden Prairie, Minneapolis, MN, USA). The values for the maximum retention force corresponded to the average of six measurements performed at each interval.

\section{Scanning Electron Microscopy (SEM)}

An EVO 50 microscope (Zeiss, Cambridge, UK) was used to examine the surfaces. One specimen from each group was randomly selected. Prior to the scanning, the specimens were subjected to a metallization process (SCD 050, Sputter Coater Metals, Bal-Tec, Lichtenstein), in order to provide better contrast of the samples.

\section{Statistical Analysis}

The data were analyzed with SPSS 21.0 statistical software (SPSS Inc., Chicago, IL, USA). The Shapiro Wilk normality test was applied and factorial (solution) ANOVA with repeated measures (time) and Bonferroni post hoc test were performed (test power=1.000; $\alpha=0.05$ ).

\section{Results}

\section{Retention Measures}

There was a significant difference between the factors time $(p<0.001)$ and solution $(p<0.001)$ and the interaction time $\times$ solution $(p<0.001)$. The behavior of the rings in response to tensile strength at experimental times can be seen in Table 2 .

Comparing the times for each solution, for DW there was no significant loss of retention throughout the evaluated period. For $C(p=0.029)$ and $S H(p<0.001)$ a significant reduction was observed after $\mathrm{T} 1$. For $C F(p=0.002)$ and $L$ $(p<0.001)$, a significant reduction was observed after T2.

Comparing the solutions in each time, there was no difference between solutions in T0. At T1, DW was similar to $L(p=1.000)$, DW was higher than $C F(p=0.047)$ and $S H$ $(p<0.001), C$ presented intermediate values. In T2, DW was higher than $\mathrm{CF}(\mathrm{p}=0.004)$ and $\mathrm{SH}(\mathrm{p}<0.001)$, L and $\mathrm{C}$ showed intermediate values. In T3, DW was higher than CF ( $p=0.051)$, $\mathrm{SH}(\mathrm{p}<0.001)$. L and C presented intermediate values.

\section{Scanning Electron Microscopy (SEM)}

The SEM findings (Fig. 3-a-I, a-II, b-I and b-II) show an unchanged nitrile surface in the DW and $C$ groups, while $\mathrm{L}, \mathrm{CF}$ and $\mathrm{SH}$ altered the surface of the nitrile (Fig. 3- c-I, c-II, d-I, d-II, e-I and e-II) after 90-day immersion simulation (T3).

In the CF group (Fig. 3- c-I and c-II), there was precipitation of a layer of crystals, and in the $L$ group, evidence of degradation could be observed (Fig. 3- d-I

Table 1. Immersion solutions

\begin{tabular}{|c|c|c|c|}
\hline Cleanser & Composition & Manufacturer & Lot \\
\hline Cepacol (C) & $\begin{array}{l}\text { Cetylpyridinium chloride } 0.500 \mathrm{mg} \text {, disodium EDTA, } \\
\text { sodium saccharin, polysorbate } 80 \text {, glycerin, sodium } \\
\text { phosphate, disodium phosphate, eucalyptol, menthol, methyl } \\
\text { salicylate, aroma, parfum (benzyl alcohol, cinnamal), CI } \\
19140 \text { and alcohol }\end{array}$ & $\begin{array}{l}\text { Sanofi-Aventis Pharmaceutical } \\
\text { Ltda., Suzano, SP, Brazil }\end{array}$ & L215304 \\
\hline Listerine (L) & $\begin{array}{l}\text { Thymol, Eucalyptol, Menthol, Methyl salicylate, water, } \\
\text { sorbitol solution, alcohol, poloxamer 407, benzoic acid, mint } \\
\text { essence, sodium saccharin, sodium benzoate and colorant. }\end{array}$ & $\begin{array}{l}\text { Johnson \& Johnson of Brazil } \\
\text { Industry and Trade of Products for } \\
\text { Health Ltda., São Paulo, SP, Brazil }\end{array}$ & 2801WL20 \\
\hline $\begin{array}{l}\text { 0.05\% Sodium } \\
\text { hypoclorite }(\mathrm{SH})\end{array}$ & - & $\begin{array}{l}\text { Q’Boa, Anhembi S/A, } \\
\text { Osasco, SP, Brazil }\end{array}$ & \\
\hline
\end{tabular}

Table 2. Calculated averages for the interaction solution $\times$ time

\begin{tabular}{lcccc}
\hline Solution & T0 & T1 & T2 & T3 \\
\hline Deionized water & $11.49(1.51)^{\mathrm{a} / \mathrm{A}}$ & $10.91(1.25)^{\mathrm{a} / \mathrm{A}}$ & $10.66(1.34)^{\mathrm{a} / \mathrm{A}}$ & $10.58(1.50)^{\mathrm{a} / \mathrm{A}}$ \\
Cepacol & $11.70(1.06)^{\mathrm{a} / \mathrm{A}}$ & $10.32(0.69)^{\mathrm{ab} / \mathrm{B}}$ & $10.14(0.72)^{\mathrm{ab} / \mathrm{BC}}$ & $9.49(0.40)^{\mathrm{ab} / \mathrm{C}}$ \\
Cepacol with fluoride & $10.58(1.60)^{\mathrm{a} / \mathrm{A}}$ & $9.46(0.79)^{\mathrm{b} / \mathrm{A}}$ & $8.52(0.93)^{\mathrm{b} / \mathrm{B}}$ & $7.99(0.42)^{\mathrm{bc} / \mathrm{B}}$ \\
Listerine & $11.97(0.58)^{\mathrm{a} / \mathrm{A}}$ & $10.75(0.52)^{\mathrm{a} / \mathrm{A}}$ & $9.10(0.91)^{\mathrm{ab} / \mathrm{B}}$ & $8.55(0.72)^{\mathrm{bc} / \mathrm{B}}$ \\
Sodium hypochlorite & $10.51(1.58)^{\mathrm{a} / \mathrm{A}}$ & $6.72(0.57)^{\mathrm{c} / \mathrm{B}}$ & $5.40(0.40)^{\mathrm{c} / \mathrm{C}}$ & $5.39(0.60)^{\mathrm{d} / \mathrm{C}}$ \\
\hline
\end{tabular}

A, B Equal capital letters indicate statistical similarity in the row ( $<<0.05)$; a, b, c, d the same lowercase letters indicate statistical similarity in the column $(\mathrm{p} \leq 0.05)$. 
and d-II), while in the SH group there was rupture of the material (Fig. 3- e-I and e-II).

\section{Discussion}

The results suggest that the null hypothesis was rejected, since immersion in cleaning solutions influenced the retention force of the o-ring attachment used in this study.

The use of overdentures has increased, and there is a need to establish a cleaning protocol for this type of denture. It is well known that a cleaning agent must be

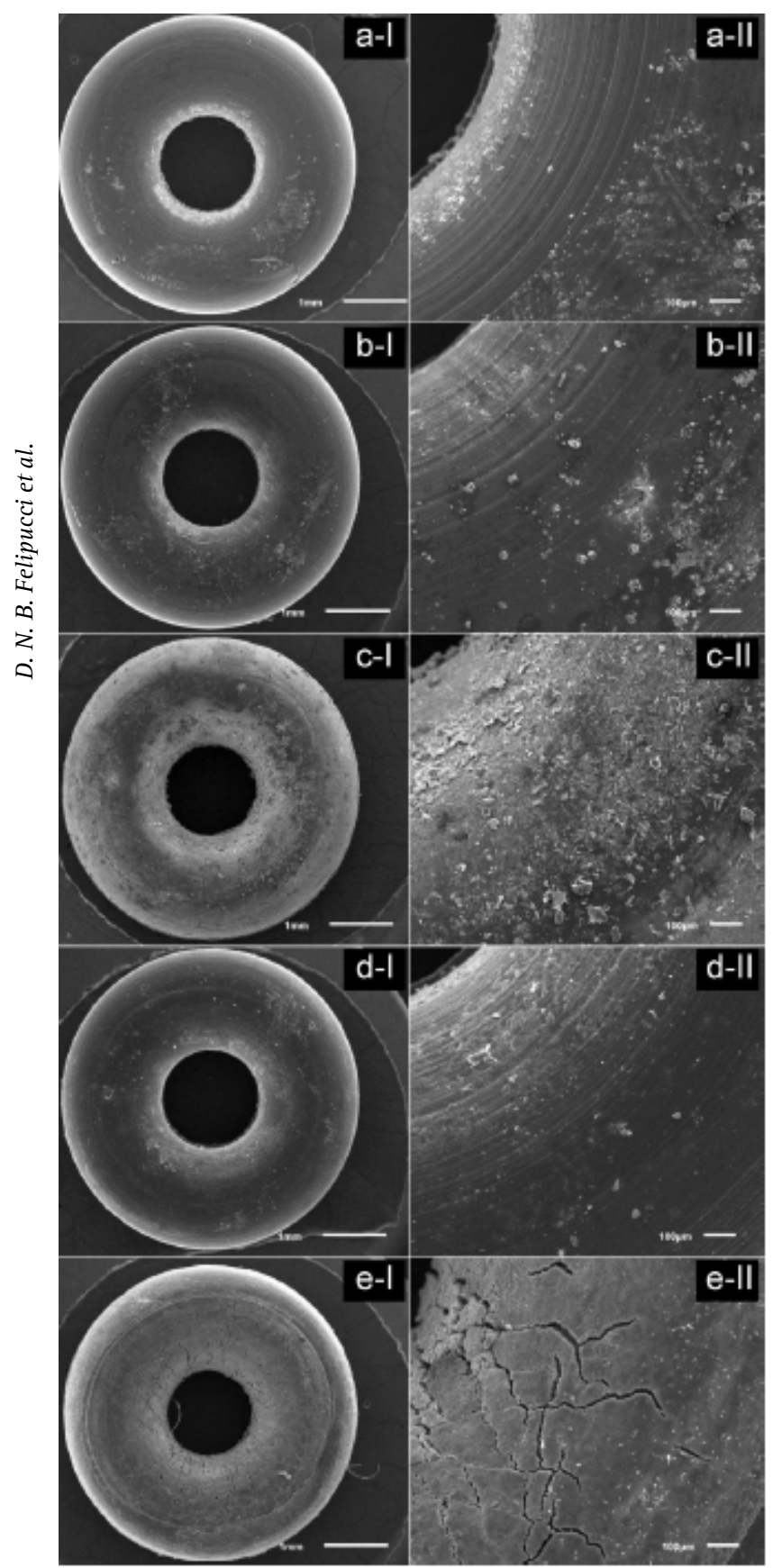

Figure 3. Scanning electron microscopy images: (a) control group (deionized water); (b) Cepacol; (c) Cepacol with fluoride; (d) Listerine; (e) sodium hypochlorite; I 20× magnification; II 100× magnification. safely indicated in addition to its antimicrobial activity, what also means it must be compatible with the different materials of a denture (21).

In this study, ball-type attachments with metal capsules and nitrile rubber rings were used as they are a popular method widely indicated for the retention of overdentures and which have satisfactory mechanical performance $(7,11,27)$.

As cleaning solutions, C, CF and L were selected due to their satisfactory antimicrobial action. Cetylpyridinium chloride is a quaternary ammonium compound capable of interacting with the bacterial cell membrane, with a broad spectrum of action, resulting in the loss of cellular components, alteration of metabolism, growth inhibition and consequent cell death (28) and Listerine is an antiseptic agent with potential health benefits, composed of a mixture of essential oils, that removes lipopolysaccharide from gram-negative bacteria and reduces microbial coaggregation (29). Furthermore, they are easily accepted by patients. 0.05\% SH solution was recommended by Barnabé et al. (22) for reducing denture stomatitis. Estrela et al. (30) pointed out the antimicrobial activity of $\mathrm{NaOCl}$ on essential enzymatic sites, promoting their irreversible inactivation via the action of hydroxyl ions and chloramination. Besides that, $\mathrm{SH}$ also acts by dissolving mucin and otherorganic substances, such as extracellular polymeric matrix (31). DW was used in the control group to avoid any interference that could occur due to the release of ions when distilled water or tap water is used $(32,33)$.

The results demonstrated that overnight cleaning for three months promoted significant changes in the rubber rings of overdentures, affecting retention.

When analyzing the different times (Table 2) there was a decrease in retention when T0 and T3 were compared, except in deionized water, however, all values obtained were above $5 \mathrm{~N}$. There has been much discussion about the minimum amount of retention force that an o-ring system must present but, according to Lehmann and Arnim (34), the ideal retention force of an attachment should be 10 to $15 \mathrm{~N}$, with a recommended minimum retention of 5 to $7 \mathrm{~N}$. Thus, in this study, considering only time, the changes in retention force are acceptable.

When analyzing the solutions, DW (control) provided higher tensile strength to the rubber rings than all the solutions evaluated, in opposition to the study by Chiu et al. (35) who did not find differences after immersion in water at the same temperature, however, the attachment used was of the pink Locator type.

Although retention force decreased after immersion in $L(8.55)$, it remained higher than recommended in the literature ( $5 \mathrm{~N}$ ) (33), after 90 days of evaluation. You et al. (18) and Nguyen et al. (15) demonstrated differently, once 
the retention of the pink Locator had increased. However, You et al. (18) stated that increased retention might not be desirable, since over time it may adversely affect the behavior of the attachments, being capable of increasing stiffness and reducing longevity (25). Besides that, the authors suggested more studies to draw a conclusion about its usage as a denture cleanser (18). Another relevant fact is that increasing the retention force above $10 \mathrm{~N}$ can lead to damage to adjacent soft and bony tissue (34). Nguyen et al. (15) reported a change in color of the attachment, leaving it bluish. In the present study, through analysis of the surface topography it was possible to identify signs of degradation, that is, cracking and dryness of the nitrile ring (Fig. 3d).

For $\mathrm{C}$, no study has evaluated its use associated with overdentures. Lessa et al. (36) and Aoun et al. (37) demonstrated its antimicrobial effect in relation to $S$. mutans and C. albicans, respectively, and preliminary studies by Felipucci et al. $(32,33)$ demonstrated that this solution does not present any adverse effect in relation to heat-polymerizable acrylic resin and cobalt-chromium alloys. In this study, in agreement with the other solutions, there was also a deleterious effect on the retention system, resulting in a reduction of retention compared to the initial one.

$\mathrm{CF}$ reduced retention of the rings $(7.99 \mathrm{~N})$ in relation to the control group over time; through analysis of the surface topography, the presence of layers of crystalline precipitate involving the whole ring was detected (Fig. 3 c-II), which may have had a lubricating action between the ring and the attachment, decreasing its retention. There are no reports in the literature that associate this solution with the retention force of this system. Some authors have studied the action of fluoride in contact with different materials such as titanium, suggesting that the presence of fluoride in dentifrices and mouthwashes may cause deleterious effects on the surface of metals, reducing their resistance and leaving them prone to corrosion (38-40). This study evaluated only the nitrile rubber ring; however, it is possible to infer, based on the micrographs, that the fluoride present in $\mathrm{C}$ probably affects this material.

Regarding $\mathrm{SH}$, it can be deduced that this solution affects retention after 90 days, reducing significantly it $(5.39 \mathrm{~N})$. These results resemble the findings of Derafshi et al. (26) and Kürkcüoglu et al. (24) who demonstrated that $\mathrm{SH}$ provides a significant loss of retention in blue Locator and orange Dio attachments, as well as those of You et al. (18) who reported a significant decrease in retention of the pink Locator attachment, after immersion in 6.15\% $\mathrm{SH}$ associated to cycling. Nguyen et al. (15) also used the same type of attachment and attributed softening and bleaching to it, in addition to loss of retention. Varghese et al. (26) found the opposite results: immersion in 5.25\% SH solution for 15 min increased retention. This result can be attributed to the characteristics and composition of a attachment system (yellow Hader clip) different to the one used in this study, besides the higher SH concentration used.

When analyzing the topographic contrast images of the SH group (Fig. 3e), there is a continuous solution throughout the surface of the nitrile ring, generating significant dimensional deformation in the diameter of the ring hole. Such alteration may explain the significant loss of retention, thus discouraging its routine use as a cleaner.

Thus, as there is no consensus among dental professionals on the best cleaning method for overdentures, this study has great clinical relevance, as Cepacol and Listerine can be used safely as cleaning solutions, as they do not reduce strength retention and do not cause deleterious effects on the nitrile surface of the o-ring, after simulation of 90 days of use.

This study presents some limitations. First are those inherent to in vitro studies in which oral cavity conditions, as well as the number of times the denture is removed from the oral cavity, are not reproducible. In addition, the speed, force and axis of insertion of the denture may vary considerably in a clinical situation.

In order to evaluate the effect isolated of cleaning solutions after the simulation of each period, other factors that could influence retention, like cycles of insertion and removal, were not performed.

Future researches should be carried on complement the results obtained in this static phase, including dynamic assays and new removable denture cleaning products simulating a longer period, in addition to conducting clinical trials.

Based on the experimental conditions of the present study and in accordance with the methodology used, after 90 days of evaluation, it was possible to conclude that, $\mathrm{CF}$ and $0.05 \%$ SH solutions, had a negative effect reducing the 0 -rings retention values below the minimum indicated $(5 \mathrm{~N})$. Therefore, they should not be recommended as daily immersion solutions for overdentures. CF and $0.05 \% \mathrm{SH}$ caused significant topographic changes in the nitrile ring of the attachment and the o-ring system was affected by these experimental solutions. However, $\mathrm{C}$ and $\mathrm{L}$ presented satisfactory results, as they did not change de surface and kept the resistance within adequate levels, proving to be the most suitable solutions for immersing o-rings.

\section{Resumo}

0 objetivo do estudo foi avaliar o efeito de soluções higienizadoras sobre a força de retenção de encaixes do tipo o-ring. Foram avaliadas quatro soluções: Cepacol (C); Cepacol com flúor (CF), Listerine (L), hipoclorito de sódio 0,05\% (HS) e água deionizada (controle/AD) em o-rings de nitrilo. Matrizes contendo dois implantes e pilares e espécimes em acrílico com as 
cápsulas metálicas foram obtidas e divididas entre os grupos. Foi realizada a simulação de 90 imersões noturnas $(8 \mathrm{~h})$, sendo obtido o valor da resistência à tração no início e a cada 30 dias (T0, T1, T2 e T3) por meio da máquina de ensaios mecânicos $(n=6)$. Microscopia eletrônica de varredura (MEV) foi utilizada para análise de danos na superfície do o'ring após a imersão $(n=1)$. Para análise estatística dos resultados foi utilizada análise de variância (ANOVA) e múltiplas comparações com ajuste de Bonferroni (poder do teste $=1,000 ; \alpha=0,05$ ). Houve diferença significante para os fatores tempo $(p<0,001)$, solução $(p<0,001)$ e para interação de tempo $\times$ solução $(p<0,001)$. Considerando-se os tempos de cada solução, apenas $A D$ não apresentou perda significativa de retenção ao longo do tempo. Comparando as soluções em cada momento, não houve diferença entre as soluções em T0. A partir de T1, CF e HS propiciaram menor retenção quando comparados à $A D(p<0,005)$. Através do MEV foi possivel observar alterações nas superficies dos o-rings de nitrilo imersos em CF e HS. 0 Cepacol com flúor e hipoclorito de sódio devem ser evitados devido à ação deletéria nos o-rings.

\section{Acknowledgments}

This research was supported by a grant from The São Paulo State Research Foundation (FAPESP; grant \#2011/20830-2).

\section{References}

1. Geckili O, Bilhan H, Mumcu E, Dayan C, Yabul A, Tuncer N. Comparison of patient satisfaction, quality of life, and bite force between elderly edentulous patients wearing mandibular two implant-supported overdentures and conventional complete dentures after 4 years. Spec Care Dentist 2012;32:136-141.

2. Arora V, Kumar D, Legha VS, Arun Kumar KV. Prospective study of treatment outcome of implant retained mandibular overdenture: Two years follow-up. Contemp Clin Dent 2014;5:155-159.

3. Park JH, Lee JY, Shin SW. Treatment outcomes for mandibular miniimplant-retained overdentures: A systematic review. Int J Prosthodont 2017;30:269-276.

4. Fernandez-Estevan L, Montero J, Selva Otaolaurruchi EJ, Sola Ruiz F. Patient-centered and clinical outcomes of mandibular overdentures retained with the locator system: A prospective observational study. J Prosthet Dent 2017;117:367-372.

5. Feine JS, Carlsson GE, Awad MA, Chehade A, Duncan WJ, Gizani S, et al. The McGill consensus statement on overdentures. Mandibular twoimplant overdentures as first choice standard of care for edentulous patients. Int J Oral Maxillofac Implants 2002;17:601-602.

6. Feine JS, Carlsson GE, Awad MA, Chehade A, Duncan WJ, Gizani S, et al. The McGill consensus statement on overdentures. Int J Prosthodont 2002;15:413-414.

7. Bilhan H, Geckili O, Mumcu E, Bilmenoglu C. Maintenance requirements associated with mandibular implant overdentures: clinical results after first year of service. J Oral Implantol 2011;37:697-704.

8. Dantas IS, Souza MB, Morais MH, Carreiro Ada F, Barbosa GA. Success and survival rates of mandibular overdentures supported by two or four implants: a systematic review. Braz Oral Res 2014;28:74-80.

9. Stoumpis $C$, Kohal RJ. To splint or not to splint oral implants in the implant-supported overdenture therapy? A systematic literature review. J Oral Rehabil 2011;38:857-869.

10. Kilic K, Koc AN, Tekinsen FF, Yildiz P, Kilic D, Zararsiz G, et al. Assessment of Candida species colonization and denture-related stomatitis in bar and locator retained overdentures. J Oral Implantol 2014;40:549-556.

11. Botega DM, Mesquita MF, Henriques GE, Vaz LG. Retention force and fatigue strength of overdenture attachment systems. J Oral Rehabil 2004;31:884-889.

12. Cepa $S$, Koller B, Spies BC, Stampf $S$, Kohal RJ. Implant-retained prostheses: ball vs. conus attachments - A randomized controlled clinical trial. Clin Oral Implants Res 2017:28:177-185.

13. Uludag B, Polat S, Sahin V, Çomut AA. Effects of implant angulations and attachment configurations on the retentive forces of locator attachment-retained overdentures. Int J Oral Maxillofac Implants
2014;29:1053-1057

14. Srinivasan $M$, Schimmel $M$, Badoud I, Ammann $P$, Herrmann FR, Müller F. Influence of implant angulation and cyclic dislodging on the retentive force of two different overdenture attachments - an in vitro study. Clin Oral Implants Res 2016;27:604-611.

15. Nguyen CT, Masri R, Driscoll CF, Romberg E. The effect of denture cleansing solutions on the retention of pink Locator attachments: an in vitro study. J Prosthodont 2010;19:226-230.

16. Budtz-Jørgensen E. Materials and methods for cleaning dentures. J Prosthet Dent 1979;42:619-623.

17. Dills SS, Olsan AM, Goldner S Goldner S, Brogdon C. Comparison of the antimicrobial capability of an abrasive paste and chemical soak denture cleansers. J Prosthet Dent 1988;60:467-470.

18. You W, Masri R, Romberg E, Driscoll CF, You T. The effect of denture cleansing solutions on the retention of pink locator attachments after multiple pulls: an in vitro study. J Prosthodont 2011;20:464-469.

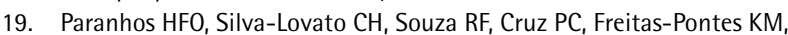
Peracini A. Effects of mechanical and chemical methods on denture biofilm accumulation. J Oral Rehabil 2007;34:606-612.

20. Axe AS, Varghese R, Bosma M, Kitson N, Bradshaw DJ. Dental health professional recommendation and consumer habits in denture cleansing. J Prosthet Dent 2016;115:183-188.

21. Kiesow A, Sarembe S, Pizzey RL, Axe AS, Bradshaw DJ. Material compatibility and antimicrobial activity of consumer products commonly used to clean dentures. J Prosthet Dent 2016;115:189-198.

22. Barnabé W, Mendonça T, Neto A, Pimenta FC, Pegoraro LF, Scolaro JM. Efficacy of sodium hypochlorite and coconut soap used as disinfecting agents in the reduction of denture stomatitis, Streptococcus mutans and Candida albicans. J Oral Rehabil 2004;31:453-459.

23. Paranhos Hde F, Peracini A, Pisani MX, Oliveira Vde C, de Souza RF, SilvaLovato $\mathrm{CH}$. Color stability, surface roughness and flexural strength of an acrylic resin submitted to simulated overnight immersion in denture cleansers. Braz Dent J 2013;24:152-156.

24. Kürkcüoglu I, Özkir SE, Köroglu A, Sahin O, Yilmaz B. Effect of denture cleansing solutions on different retentive attachments. J Prosthet Dent 2016;115:606-610.

25. Varghese RM, Masri R, Driscoll CF, Romberg E. The effect of denture cleansing solutions on the retention of yellow Hader clips: an in vitro study. J Prosthodont 2007;16:165-171.

26. Derafshi R, Mohaghegh M, Saki M, Safari, Rabee Haghighi M. The effects of denture cleansing solutions on the retention of attachments of implant supported overdentures. J Dent 2016;16:68-72.

27. El-Anwar MI, El-Taftazany EA, Hamed HA, ElHay MAA. Influence of Number of Implants and Attachment Type on Stress Distribution in Mandibular Implant-Retained Overdentures: Finite Element Analysis. Open Access Maced J Med Sci 2017;5:244-249.

28. Sreenivasan PK, Haraszthy VI, Zambon JJ. Antimicrobial efficacy of $0.05 \%$ cetylpyridinium chloride mouthrinses. Lett Appl Microbiol 2012;56:14-20.

29. Fine DH, Letizia J, Mandel ID. The effect of rinsing withListerine antiseptic on the properties of developingdental plaque. J Clin Periodontol 1985;12:660-666.

30. Estrela C, Estrela CR, Barbin EL, Spanó JC, Marchesan MA, Pécora JD. Mechanism of action of sodium hypochlorite. Braz Dent J 2002;13:113凶117.

31. Nikawa $H$, Hamada $T$, Yamashiro $H$, Kumagai $H$. A review of in vitro and in vivo methods to evaluate the efficacy of denture cleansers. Int J Prosthodont 1999;12:153区159.

32. Felipucci DNB, Davi LR, Paranhos HFO, Bezzon OL, Silva RF, Junior FB, et al. Effect of different cleansers on the weight ion release of removable partial denture: an in vitro study. J Appl Oral Sci 2011;19:483-487.

33. Felipucci DNB, Davi LR, Paranhos HFO, OL Bezzon, Silva RF, Pagnano VO. Effect of different cleansers on the surface of removable partial denture. Braz Dent J 2011;22:392-397.

34. Lehmann KM, Arnim FV. Studies on the retention forces of snap-on attachments. Quint Dent Technol 1978;7:45-48.

35. Chiu LPY, Vitale ND, Petridis H, McDonald A. The effect of different water temperatures on retention loss and material degradation of locator attachments. J Prosthodont 2017;26:537-544. 
36. Lessa FC, Enoki C, Ito IY, Faria G, Matsumoto MA, Nelson-Filho P. Invivo evaluation of the bacterial contamination and disinfection of acrylic baseplates of removable orthodontic appliances. Am J Orthod Dentofacial Orthop 2007;131:705.e11-7.

37. Aoun G, Cassia A, Berberi A. Effectiveness of a chlorhexidine digluconate $0.12 \%$ and cetylpyridinium chloride $0.05 \%$ solution in eliminating Candida albicans colonizing dentures: A randomized clinical in vivo study. J Contemp Dent Pract 2015;16:433-436.

38. Golvano I, Garcia I, Conde A, Tato W, Aginagalde AJ. Influence of fluoride content and $\mathrm{pH}$ on corrosion and tribocorrosion behaviour of Ti13Nb13Zr alloy in oral environment. Mech Behav Biomed Mater
2015:49:186-196.

39. Huang GY, Jiang HB, Cha JY, Kim KM. The effect of fluoride-containing oral rinses on the corrosion resistance of titanium alloy (Ti-6Al-4V). Korean J Orthod 2017:47:306-312

40. Fukushima A, Mayanagi G, Sasaki K, Takahashi N. Corrosive effects of fluoride on titanium under artificial biofilm. J Prosthodont Res 2018;62:104-109. 